Communication

\title{
Sources of Resistance to Powdery Mildew in Barley Landraces from Turkey
}

\author{
Jerzy H. Czembor *(D) and Elżbieta Czembor (1)
}

check for updates

Citation: Czembor, J.H.; Czembor, E. Sources of Resistance to Powdery Mildew in Barley Landraces from Turkey. Agriculture 2021, 11, 1017. https://doi.org/10.3390/ agriculture11101017

Academic Editor: Ana

Isabel López-Sesé

Received: 13 September 2021

Accepted: 14 October 2021

Published: 17 October 2021

Publisher's Note: MDPI stays neutral with regard to jurisdictional claims in published maps and institutional affiliations.

Copyright: (c) 2021 by the authors. Licensee MDPI, Basel, Switzerland. This article is an open access article distributed under the terms and conditions of the Creative Commons Attribution (CC BY) license (https:// creativecommons.org/licenses/by/ $4.0 /)$.
Plant Breeding and Acclimatization Institute-National Research Institute (IHAR-PIB), Radzikow, 05-870 Blonie, Poland; e.czembor@ihar.edu.pl

* Correspondence: j.h.czembor@ihar.edu.pl

\begin{abstract}
Powdery mildew on barley, caused by the pathogen Blumeria graminis f. sp. hordei, occurs worldwide and can result in severe yield loss. Germplasm of barley, including landraces, commercial cultivars, wild relatives and breeding lines are stored in more than 200 institutions. There is a need for characterization of this germplasm in terms of resistance to biotic and abiotic stresses. This is necessary in order to use specific accessions in breeding programs. In the present study, 129 barley landraces originated from Turkey and provided by the ICARDA genebank were tested for resistance to powdery mildew. Seedling resistance tests after inoculation with 19 differentiated isolates of B. graminis f. sp. hordei were used to postulate the presence of resistance genes. From the 129 landraces studied, plants of 19 (14.7\%) of them showed resistance to infection with powdery mildew. Based on preliminary tests from these 19 landraces, 25 resistant single plant lines were selected for testing with differential powdery mildew isolates. Seven lines were resistant to all 19 isolates used. However, only one line (5583-1-4) showed resistance scores of zero against all isolates used. It is likely that this line possesses unknown, but highly effective genes for resistance. In five resistant lines it was not possible to postulate the presence of specific resistance genes. In 19 lines the presence of the genes Mlp, Mlk, Mlh, Mlg, Ml(CP), Mlat, Mla3, Mla6, Mla7 and Mla22 were postulated. These new sources of highly effective powdery mildew resistance in barley landraces from Turkey could be successfully used in breeding programs.
\end{abstract}

Keywords: Hordeum vulgare; barley; Blumeria graminis; powdery mildew; landraces; germplasm; resistance genes; genebank

\section{Introduction}

Barley (Hordeum vulgare L.) is an economically important cereal crop which is known to be drought, cold, and salt tolerant and well-adapted to low-input environmental conditions [1,2]. It is cultivated at high altitudes and commonly under rain-fed conditions. It is often grown in marginal agricultural areas with low annual precipitation, often less than $220 \mathrm{~mm}$ [3]. Barley ranks as the fourth crop in the world, after wheat, maize and rice, in terms of the area of cultivation. Almost half of the world's barley area is in Europe, where barley is second crop after wheat in cultivated area [4].

Germplasm of barley, including landraces, commercial cultivars, wild relatives and breeding lines is very diverse and is stored in more than 200 institutions [5,6]. Barley landraces are an important source of genetic variation and resistance to biotic stresses including powdery mildew [7-9]. Turkey is characterized by the presence of diverse agroecological zones and a long history of agriculture. It is known to be a rich source of barley landraces. They are still planted in this country, and they are characterized by a high level of resistance to biotic and abiotic stresses. There is a need for characterization of this germplasm in terms of resistance to biotic and abiotic stresses. This knowledge is necessary in order to use specific accessions in breeding programs [10-12].

Barley is often infected by barley powdery mildew fungus (Blumeria graminis DC. Golovin ex Speer f. sp. hordei). Loss of yield caused by this disease can reach up to 
$30 \%$, with averages of $5-10 \%$ [13-16]. Powdery mildew on barley is considered one of the most well-characterized host-pathogen genetic interaction systems. Barley cultivars with effective genes for resistance to powdery mildew have been an efficient means for controlling this disease [17-21]. Barley breeders have used major resistance genes: Mla6, Mla7, Mla9, Mla12 and Mla13, Mlk, Mlg, MlLa, Mlh and Mlra, which originated from landraces as well as from the subspecies $H$. vulgare ssp. spontaneum. Durable mlo-resistance (gene $\mathrm{mlo}$ ) has been identified in landraces. Since 1984, it has been deployed in many barley cultivars throughout Europe [20,22-24].

Effective controlling of barley powdery mildew is possible by growing genetically resistant barley cultivars. This method of crop protection is relatively inexpensive and it is environmentally friendly. These cultivars started being used from the beginning of the application of modern, intensive methods in barley production because these production methods created favorable conditions for development of this disease [25-30]. Currently, powdery mildew of barley is one of the most common and most widespread disease of barley in Europe and another barley regions of the world, causing significant yield losses [20,21,31].

When a cultivar containing one dominant resistance gene is grown on a large acreage, new virulent $B$. graminis races may occur within $4-5$ years. Exceptions are recessive genes for resistance such as $m l f$ and $m l o$. However, many factors, e.g., temperature, water stress or light intensity, may affect the use of these genes in breeding programmes [20,22,28]. At least 38 different genes/alleles have been used in varieties grown in Europe [32]. Nevertheless, barley breeders, geneticists and plant pathologists are constantly looking for new, efficient sources of powdery mildew resistance, in order to combine them with those already used in modern cultivars, and to increase their resistance durability [31,33,34].

Most of the original sources of powdery mildew resistance genes came from domesticated cultivars in Europe $[25,26,35]$. These sources of resistance were easy to be used in breeding but the number of resistance genes was limited. Breeders and geneticists have been looking for new sources of resistance in non-European germplasm. Most of these studies were conducted using collections of landraces and differential sets of powdery mildew isolates [36,37]. Previous studies showed that barley landraces from Turkey are rich sources of genetic diversity for plant breeding, including resistance to pathogens [10-12,38,39].

Identification of powdery mildew resistance genes based on tests performed on seedlings using differential sets of pathogens is effective and sufficient for breeders' and pathologists' needs $[25,30,40,41]$. This study aimed at detecting sources of powdery mildew resistance in barley landraces from Turkey.

\section{Materials and Method}

\subsection{Plant Material}

Seed samples of $129 \mathrm{H}$. vulgare L. landraces from Turkey were provided by Dr. J. Valkoun, J. Konopka and Prof. S. Ceccarelli (International Center for Agricultural Research in the Dry Areas-ICARDA, Aleppo, Syria) (Table 1). For 53 landraces, details about the places of collection were known. These landraces originated from 26 provinces: 11 landraces were from Ismir province, 4-Kars, 3-Eskisehir, 3-Agri, 3-Erzincan, 3-Sivas, 3-Mugla, 3-Bilecik, 3-Kayseri, 2-Kutahya and 1 landrace originated from each of the following provinces-Bayburt, Denizli, Sanli Urfa, Manisa, Van, Mus, Hakkari, Tokat, Icel, Antakya, Gaziantep, Isparta, Adana, Afyon, Usak, and Bursa. They were collected at altitudes from $15 \mathrm{~m}$ above sea level in Izmir province, to $1900 \mathrm{~m}$ above sea level in Kars province, and $2250 \mathrm{~m}$ above sea level in Bayburt province.

\subsection{Pathogen}

Nineteen differential Bgh (B. graminis f. sp. hordei Em Marschal) isolates with virulence genes corresponding to known resistance genes were used (Table 2). Isolates originated from the collections in Risø National Laboratory, Roskilde, Denmark; Danish Institute for Plant and Soil Science, Lyngby, Denmark; Edigenossische Technische Hochschule-ETH, 
Zurich, Switzerland provided kindly by Dr. H. J. Schaerer (ETH, Zurich, Switzerland) and the Plant Breeding and Acclimatization Institute-National Research Institute (PBAINRI) IHAR, Radzikow, Poland. A set of isolines of barley cultivar Pallas with different resistance genes was used [42], provided by Dr. L. Munk (Royal Agricultural and Veterinary University, Copenhagen, Denmark) and on 8 additional cultivars.

Isolate $B g h 33$ was the most avirulent isolate. It was avirulent to resistance genes, or their combinations, such as: Mla1, Mla3, Mla + Mla14, Mla7 + Mlk +?, Mla7 +?, Mla + MlLG2, Mla9 + Mlk, Mla9, Mla12, Mla13 + MlRu3, Mla22, Mla23, MlRu2, Mlk, Mlp, Mlat and to resistance genes present in additional cultivars included in a differential set: Benedicte (Mla9,Ml(IM9), Lenka (Mla13,Ml(Ab), Steffi (Ml(St1), Ml(St2), and Kredit Ml(Kr). Isolates Bgh 1, Bgh 29, and Bgh 51 were the most virulent group. Isolate $B g h 51$ was virulent to resistance genes or their combinations present in 18 Pallas isolines, Bgh 29 was virulent to resistance genes or their combinations present in 17 Pallas isolines and $B g h 1$ virulent to resistance genes or their combinations present in 16 Pallas isolines. They were purified by single pustule isolation and were maintained and propagated on young seedlings of the powdery mildew-susceptible cultivar Manchuria (CI 2330). Virulence checks were conducted to assure the purity of isolates throughout the experiment.

A five-point ( 0 to 4 ) reaction type (RT) scale was used, as follows: 0 , no visible symptoms; 1 , minute necrotic flecks, no mycelial growth and no sporulation; 2 , frequent chlorosis, reduced mycelial growth and no or very scarce sporulation; 3 , moderate mycelial growth, moderate sporulation, and occasional chlorosis; 4 , profuse sporulation of welldeveloped colonies, $0(4)$ sparse small colonies originating from the stomatal subsidiary cells $[26,43]$.

\subsection{Landraces and Single Plant-Lines Resistance Tests}

First, samples of 30 plants from each of the landraces were tested with the Bgh 33 isolate (the most avirulent one) under controlled chamber conditions with a $16 / 8 \mathrm{~h}$ day /night photoperiod and a $22 / 16^{\circ} \mathrm{C}$ temperature regime.

Seedlings with a fully expanded first leaf were inoculated with $B g h$ isolate by shaking conidia from the susceptible cv. Manchuria. After 8-10 days, infection types were scored. Plants with disease scores of 0 to 1 were classified as highly resistant $(\mathrm{R})$, plants that scored 2 as a moderately resistant (M) and rating of 3 or 4 as susceptible and very susceptible (S). Plants with the score 0(4) possess a resistance gene in locus Mlo. The cultivar Manchurian CI 3230 was used as a susceptible control.

Based on the results of this preliminary experiment, 25 resistant single plant lines from 19 landraces were selected. A highly resistant reaction type was observed on 13 lines, and a moderately resistant reaction type was observed on 11 lines. In 5 landraces, segregation of RT was observed (Table 3). Next, they were grown in greenhouse conditions to obtain seeds for future evaluations using a set of $19 \mathrm{Bgh}$ differential isolates.

Postulation of resistant genes in tested lines was based on a comparison of reaction spectra observed on tested plants and the barley differential set infected with differential $B g h$ isolates (Table 1). This was performed on the basis of the gene-for-gene hypothesis [44]. 
Table 1. Collected data of 129 landraces from Turkey.

\begin{tabular}{|c|c|c|c|c|c|c|c|c|c|c|c|c|c|}
\hline No. & $\begin{array}{c}\text { ICARDA } \\
\text { IG }\end{array}$ & IHAR No & $\begin{array}{l}\text { Longitude } \\
\text { (E) }\end{array}$ & $\begin{array}{l}\text { Latitude } \\
\text { (N) }\end{array}$ & $\begin{array}{c}\text { Altitude } \\
\text { (ppm) }\end{array}$ & Province & No. & $\begin{array}{c}\text { ICARDA } \\
\text { IG }\end{array}$ & IHAR No & Longitude & Latitude & Altitude & Province \\
\hline 1 & 18,781 & 5177 & - & - & - & - & 66 & 115,938 & 5468 & E28 22 & N37 13 & - & Mugla \\
\hline 2 & 18,848 & 5178 & 31 32-E & N39 27 & - & Eskisehir & 67 & 115,939 & 5469 & - & - & - & - \\
\hline 3 & 18,849 & 5179 & E31 32-E & N39 27 & - & Eskisehir & 68 & 115,940 & 5470 & - & - & - & - \\
\hline 4 & 18,851 & 5180 & E27 11 & N39 07 & - & Izmir & 69 & 115,946 & 5471 & E28 53 & N40 35 & - & Bursa \\
\hline 5 & 19,056 & 5181 & - & - & - & - & 70 & 115,947 & 5472 & - & - & - & - \\
\hline 6 & 19,058 & 5182 & - & - & - & - & 71 & 115,948 & 5473 & - & - & - & - \\
\hline 8 & 19,068 & 5184 & E27 11 & N39 07 & - & Izmir & 73 & 115,958 & 5475 & - & - & - & - \\
\hline 9 & 19,077 & 5185 & - & - & - & - & 74 & 19,711 & 5511 & - & - & - & Usak \\
\hline 10 & 18,541 & 5186 & E28 38 & N38 33 & - & Manisa & 75 & 19,742 & 5512 & - & - & - & Afyon \\
\hline 11 & 19,545 & 5187 & - & - & - & - & 76 & 19,909 & 5513 & - & - & - & Kutahya \\
\hline 12 & 19,546 & 5188 & - & - & - & - & 77 & 19,920 & 5514 & - & - & - & Kutahya \\
\hline 13 & 19,547 & 5189 & - & - & - & - & 78 & 19,929 & 5515 & - & - & - & Bilecik \\
\hline 14 & 19,550 & 5190 & - & - & - & - & 79 & 19,992 & 5516 & - & - & - & Bilecik \\
\hline 16 & 19,565 & 5192 & - & - & - & - & 81 & 26,758 & 5524 & - & - & - & - \\
\hline 17 & 19,566 & 5193 & - & - & - & - & 82 & 27,189 & 5525 & E35 29 & N38 44 & - & Kayseri \\
\hline 18 & 19,568 & 5194 & - & - & - & - & 83 & 27,246 & 5526 & E30 32 & N37 46 & - & Isparta \\
\hline 19 & 19,569 & 5195 & - & - & - & - & 84 & 27,251 & 5527 & E37 21 & N37 08 & - & Gaziantep \\
\hline 20 & 19,576 & 5196 & E27 11 & N39 07 & - & Izmir & 85 & 28,537 & 5532 & E36 34 & N36 16 & - & Antakya \\
\hline 21 & 37,224 & 5340 & - & - & - & - & 86 & 28,543 & 5533 & E33 39 & N36 21 & - & Icel \\
\hline 22 & 37,225 & 5341 & - & - & - & - & 87 & 28,675 & 5534 & E35 37 & N40 17 & - & Tokat \\
\hline 23 & 37,230 & 5342 & - & - & - & - & 88 & 28,676 & 5535 & E4306 & N40 37 & - & Kars \\
\hline 24 & 37,234 & 5343 & - & - & - & - & 89 & 28,704 & 5536 & E35 22 & N38 11 & - & Kayseri \\
\hline 25 & 37,235 & 5344 & - & - & - & - & 90 & 28,706 & 5537 & E4304 & N39 44 & - & Agri \\
\hline 26 & 37,237 & 5345 & - & - & - & - & 91 & 28,728 & 5538 & E38 29 & N39 16 & - & Erzincan \\
\hline 27 & 37,239 & 5346 & - & - & - & - & 92 & 28,734 & 5539 & E36 36 & N39 52 & - & Sivas \\
\hline 28 & 37,240 & 5347 & - & - & - & - & 93 & 28,809 & 5540 & E44 02 & N39 34 & - & Agri \\
\hline 29 & 37,241 & 5348 & - & - & - & - & 94 & 28,811 & 5541 & - & - & 702 & Hakkari \\
\hline
\end{tabular}


Table 1. Cont.

\begin{tabular}{|c|c|c|c|c|c|c|c|c|c|c|c|c|c|}
\hline No. & $\begin{array}{l}\text { ICARDA } \\
\text { IG }\end{array}$ & IHAR No & $\begin{array}{l}\text { Longitude } \\
\text { (E) }\end{array}$ & $\begin{array}{l}\text { Latitude } \\
\text { (N) }\end{array}$ & $\begin{array}{c}\text { Altitude } \\
\text { (ppm) }\end{array}$ & Province & No. & $\begin{array}{l}\text { ICARDA } \\
\text { IG }\end{array}$ & IHAR No & Longitude & Latitude & Altitude & Province \\
\hline 30 & 37,242 & 5349 & - & - & - & - & 95 & 28,817 & 5542 & - & - & - & Mus \\
\hline 31 & 37,243 & 5350 & - & - & - & - & 96 & 28,859 & 5543 & E29 59 & N40 10 & - & Bilecik \\
\hline 32 & 37,244 & 5351 & - & - & - & - & 97 & 28,860 & 5544 & - & - & - & Van \\
\hline 33 & 37,246 & 5352 & - & - & - & - & 98 & 32,679 & 5546 & E43 02 & N41 01 & 1900 & Kars \\
\hline 34 & 37,249 & 5353 & - & - & - & - & 99 & 32,683 & 5547 & E36 55 & N39 48 & 1310 & Sivas \\
\hline 35 & 37,250 & 5354 & - & - & - & - & 100 & 32,684 & 5548 & E27 03 & N38 34 & 15 & Izmir \\
\hline 37 & 37,252 & 5356 & - & - & - & - & 102 & 35,531 & 5554 & E43 02 & N41 01 & 1900 & Kars \\
\hline 38 & 37,255 & 5357 & - & - & - & - & 103 & 35,532 & 5555 & E40 00 & N40 01 & 2250 & Bayburt \\
\hline 39 & 37,257 & 5358 & - & - & - & - & 104 & 35,533 & 5556 & E40 23 & N39 47 & 1420 & Erzincan \\
\hline 40 & 37,258 & 5359 & - & - & - & - & 105 & 35,534 & 5557 & E40 23 & N39 47 & 1420 & Erzincan \\
\hline 41 & 37,260 & 5360 & - & - & - & - & 106 & 35,535 & 5558 & E36 55 & N39 48 & 1310 & Sivas \\
\hline 42 & 37,262 & 5361 & - & - & - & - & 107 & 35,536 & 5559 & E27 03 & N38 34 & 15 & Izmir \\
\hline 43 & 37,266 & 5362 & - & - & - & - & 108 & 35,867 & 5563 & E28 22 & N37 13 & - & Mugla \\
\hline 45 & 37,269 & 5364 & - & - & - & - & 110 & 37,226 & 5569 & - & - & - & - \\
\hline 46 & 37,271 & 5365 & - & - & - & - & 111 & 37,227 & 5570 & - & - & - & - \\
\hline 47 & 37,273 & 5366 & - & - & - & - & 112 & 37,228 & 5571 & - & - & - & - \\
\hline 48 & 37,275 & 5367 & - & - & - & - & 113 & 37,229 & 5572 & - & - & - & \\
\hline 49 & 37,285 & 5368 & - & - & - & - & 114 & 37,223 & 5573 & - & - & - & - \\
\hline 50 & 112,919 & 5430 & E27 32 & N38 01 & - & Izmir & 115 & 37,236 & 5574 & - & - & - & - \\
\hline 51 & 112,942 & 5431 & - & - & - & - & 116 & 37,238 & 5575 & - & - & - & \\
\hline 52 & 112,995 & 5432 & - & - & - & - & 117 & 37,245 & 5576 & - & - & - & - \\
\hline 53 & 113,006 & 5433 & - & - & - & - & 118 & 37,248 & 5577 & - & - & - & - \\
\hline 54 & 113,008 & 5434 & - & - & - & - & 119 & 37,253 & 5578 & - & - & - & - \\
\hline 55 & 113,009 & 5435 & E27 32 & N38 01 & - & Izmir & 120 & 37,256 & 5579 & - & - & - & - \\
\hline 56 & 113,010 & 5436 & E27 32 & N38 01 & - & Izmir & 121 & 37,259 & 5580 & - & - & - & - \\
\hline 57 & 113,011 & 5437 & E31 32 & N39 27 & - & Eskisehir & 122 & 37,261 & 5581 & - & - & - & - \\
\hline
\end{tabular}


Table 1. Cont.

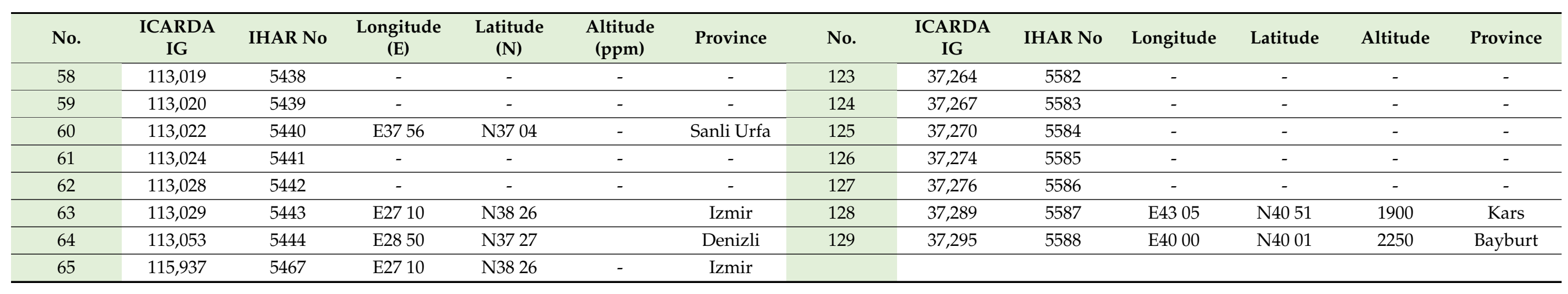

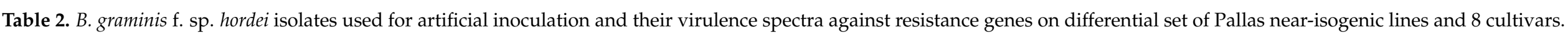

\begin{tabular}{|c|c|c|c|c|c|c|c|c|c|c|c|c|c|c|c|c|c|c|c|c|c|}
\hline \multirow{2}{*}{ No. } & \multirow{2}{*}{$\begin{array}{c}\text { Pallas } \\
\text { Isolines and } \\
\text { Cultivars } \\
\end{array}$} & \multirow{2}{*}{ Virulence } & \multicolumn{19}{|c|}{ Bgh Isolates } \\
\hline & & & Bgh 1 & Bgh 2 & Bgh 4 & Bgh 8 & Bgh 9 & Bgh 11 & Bgh 13 & Bgh 14 & Bgh 24 & Bgh 28 & Bgh 29 & Bgh 31 & Bgh 33 & Bgh 36 & Bgh 40 & Bgh 48 & Bgh 51 & Bgh 57 & Bgh 63 \\
\hline 1 & P1 & Mla1 & 0 & 0 & 4 & 4 & 0 & 0 & 0 & 0 & 0 & 0 & 4 & 0 & 0 & 4 & 0 & 0 & 4 & 0 & 0 \\
\hline 2 & P2 & Mla3 & 1 & 0 & 0 & 0 & 0 & 0 & 0 & 0 & 0 & 0 & 4 & 0 & 0 & 4 & 4 & 0 & 0 & 0 & 0 \\
\hline 3 & P3 & Mla6, Mla14 & 0 & 0 & 0 & 0 & 0 & 4 & 0 & 4 & 0 & 4 & 0 & 0 & 0 & 4 & 4 & 4 & 4 & 4 & 4 \\
\hline 4 & P4A & $\begin{array}{c}\text { Mla7, Mlk, } \\
+?\end{array}$ & 2 & 2 & 2 & 2 & 2 & 2 & 2 & 2 & 2 & 4 & 2 & 4 & 0 & 2 & 2 & 2 & 4 & 4 & 2 \\
\hline 5 & P4B & Mla,$+?$ & 4 & 4 & 1 & 0 & 2 & 2 & 4 & 4 & 0 & 2 & 4 & 4 & 1 & 4 & 4 & 1 & 4 & 4 & 4 \\
\hline 6 & P6 & $\begin{array}{c}\text { Mla7, } \\
\text { MlLG2 }\end{array}$ & 4 & 4 & 0 & 0 & 2 & 1 & 2 & 4 & 0 & 2 & 2 & 4 & 0 & 4 & 2 & 0 & 4 & 4 & 4 \\
\hline 8 & P8A & Mla9, Mlk & 4 & 0 & 0 & 0 & 0 & 0 & 4 & 0 & 0 & 0 & 4 & 0 & 0 & 0 & 0 & 0 & 0 & 4 & 0 \\
\hline 9 & Р8B & Mla9 & 4 & 0 & 0 & 0 & 0 & 0 & 4 & 0 & 4 & 0 & 4 & 0 & 0 & 0 & 0 & 0 & 0 & 4 & 0 \\
\hline 10 & P9 & $\begin{array}{l}\text { Mla10, } \\
\text { MlDu2 }\end{array}$ & 4 & 4 & 0 & 1 & 4 & 0 & 4 & 0 & 2 & 0 & 4 & 4 & 4 & 4 & 0 & 0 & 4 & 4 & 4 \\
\hline 11 & P10 & Mla12 & 0 & 0 & 0 & 0 & 4 & 0 & 0 & 4 & 0 & 0 & 4 & 4 & 0 & 4 & 4 & 0 & 4 & 0 & 4 \\
\hline 12 & P11 & $\begin{array}{l}\text { Mla13, } \\
\text { MlRu3 }\end{array}$ & 4 & 0 & 0 & 0 & 0 & 0 & 0 & 4 & 4 & 0 & 0 & 4 & 0 & 0 & 0 & 0 & 4 & 0 & 4 \\
\hline 13 & P12 & Mla22 & 4 & 4 & 4 & 4 & 0 & 4 & 0 & 4 & 4 & 4 & 4 & 4 & 0 & 0 & 4 & 4 & 4 & 0 & 0 \\
\hline 14 & P13 & Mla23 & 1 & 1 & 1 & 2 & 1 & 2 & 1 & 1 & 1 & 1 & 2 & 1 & 1 & 1 & 1 & 1 & 1 & 1 & 1 \\
\hline 15 & P14 & Mlra & 4 & 4 & 0 & 4 & 4 & 4 & 4 & 0 & 4 & 4 & 4 & 4 & 4 & 4 & 4 & 4 & 4 & 4 & 4 \\
\hline 16 & P15 & $M l(R u 2)$ & 4 & 4 & 4 & 3 & 4 & 2 & 4 & 4 & 2 & 0 & 4 & 4 & 2 & 4 & 4 & 4 & 4 & 4 & 4 \\
\hline 18 & P18 & Mlnn & 4 & 4 & 4 & 4 & 2 & 4 & 4 & 4 & 2 & 2 & 4 & 4 & 4 & 4 & 4 & 4 & 4 & 2 & 2 \\
\hline
\end{tabular}


Table 2. Cont.

\begin{tabular}{|c|c|c|c|c|c|c|c|c|c|c|c|c|c|c|c|c|c|c|c|c|c|}
\hline \multirow{2}{*}{ No. } & \multirow{2}{*}{$\begin{array}{c}\text { Pallas } \\
\text { Isolines and } \\
\text { Cultivars }\end{array}$} & \multirow{2}{*}{ Virulence } & \multicolumn{19}{|c|}{ Bgh Isolates } \\
\hline & & & Bgh 1 & Bgh 2 & Bgh 4 & Bgh 8 & Bgh 9 & Bgh 11 & Bgh 13 & Bgh 14 & Bgh 24 & Bgh 28 & Bgh 29 & Bgh 31 & Bgh 33 & Bgh 36 & Bgh 40 & Bgh 48 & Bgh 51 & Bgh 57 & Bgh 63 \\
\hline 19 & P19 & Mlp & 2 & 2 & 2 & 2 & 2 & 2 & 2 & 2 & 2 & 2 & 2 & 2 & 2 & 2 & 2 & 2 & 2 & 2 & 2 \\
\hline 20 & $\mathrm{P} 20$ & Mlat & 2 & 2 & 4 & 2 & 2 & 2 & 4 & 2 & 2 & 2 & 2 & 2 & 2 & 2 & 4 & 2 & 4 & 2 & 2 \\
\hline 21 & $\mathrm{P} 22$ & mlo5 & $0(4)$ & $0(4)$ & $0(4)$ & $0(4)$ & $0(4)$ & 3 & $0(4)$ & $0(4)$ & $0(4)$ & $0(4)$ & $0(4)$ & $0(4)$ & $0(4)$ & $0(4)$ & $0(4)$ & $0(4)$ & $0(4)$ & $0(4)$ & $0(4)$ \\
\hline 22 & P23 & $M l(L a)$ & 4 & 4 & 4 & 4 & 2 & 4 & 4 & 4 & 4 & 4 & 4 & 4 & 4 & 4 & 4 & 4 & 4 & 4 & 4 \\
\hline 23 & P24 & Mlh & 4 & 4 & 0 & 4 & 4 & 4 & 4 & 4 & 4 & 4 & 4 & 4 & 4 & 0 & 4 & 4 & 4 & 4 & 4 \\
\hline 24 & $\mathrm{P} 21$ & $\begin{array}{c}\text { Mlg, } \\
M l(C P)\end{array}$ & 4 & 4 & 0 & 0 & 0 & 4 & 0 & 4 & 0 & 4 & 4 & 4 & 4 & 4 & 4 & 0 & 4 & 0 & 4 \\
\hline 25 & $\begin{array}{l}\text { Pallas } \\
\end{array}$ & Mla8 & 4 & 4 & 4 & 4 & 4 & 4 & 4 & 4 & 4 & 4 & 4 & 4 & 4 & 4 & 4 & 4 & 4 & 4 & 4 \\
\hline 27 & Borwina & $M l(B w)$ & 4 & 3 & 0 & 4 & 0 & 4 & 4 & 4 & 2 & 2 & 3 & 4 & 4 & 4 & 3 & 4 & 4 & 2 & 2 \\
\hline 28 & Gunnar & $\begin{array}{c}\text { Mla3, } \\
\text { Ml(Tu2) }\end{array}$ & 0 & 0 & 0 & 0 & 0 & 0 & 0 & 0 & 0 & 0 & 0 & 0 & 0 & 0 & 0 & 0 & 0 & 0 & 0 \\
\hline 29 & Jarek & $M l(K r),+?$ & 4 & 4 & 4 & 4 & 2 & 4 & 4 & 4 & 4 & 4 & 4 & 4 & 4 & 4 & 2 & 4 & 4 & 2 & 4 \\
\hline 30 & Kredit & $M l(K r)$ & 4 & 2 & 0 & 2 & 0 & 0 & 2 & 4 & 4 & 4 & 2 & 4 & 0 & 4 & 2 & 2 & 4 & 4 & 4 \\
\hline 31 & Lenka & Mla13,Ml(Ab) & 4 & 0 & 0 & 0 & 0 & 0 & 0 & 4 & 0 & 0 & 0 & 4 & 0 & 0 & 0 & 0 & 4 & 0 & 4 \\
\hline 32 & Steffi & $\begin{array}{l}M l(S t 1) \\
M l(S t 2)\end{array}$ & 2 & 2 & 0 & 0 & 0 & 0 & 0 & 4 & 0 & 0 & 2 & 3 & 0 & 4 & 2 & 0 & 2 & 0 & 4 \\
\hline 33 & Trumph & $\begin{array}{c}\text { Mla7, } \\
M l(A b)\end{array}$ & 4 & 4 & 4 & 4 & 4 & 4 & 4 & 4 & 4 & 4 & 4 & 4 & 4 & 4 & 4 & 4 & 4 & 4 & 4 \\
\hline 34 & Manchuria & - & 4 & 4 & 4 & 4 & 4 & 4 & 4 & 4 & 4 & 4 & 4 & 4 & 4 & 4 & 4 & 4 & 4 & 4 & 4 \\
\hline
\end{tabular}

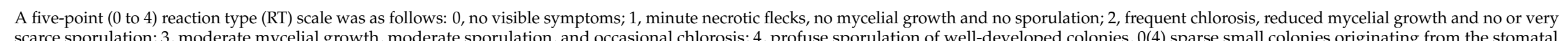
scarce sporulation;
subsidiary cells. 
Table 3. Resistance of barley (H. vulgare L.) lines selected from landraces originating from Turkey to B. graminis f. sp. hordei isolates after inoculation at the seedling stage.

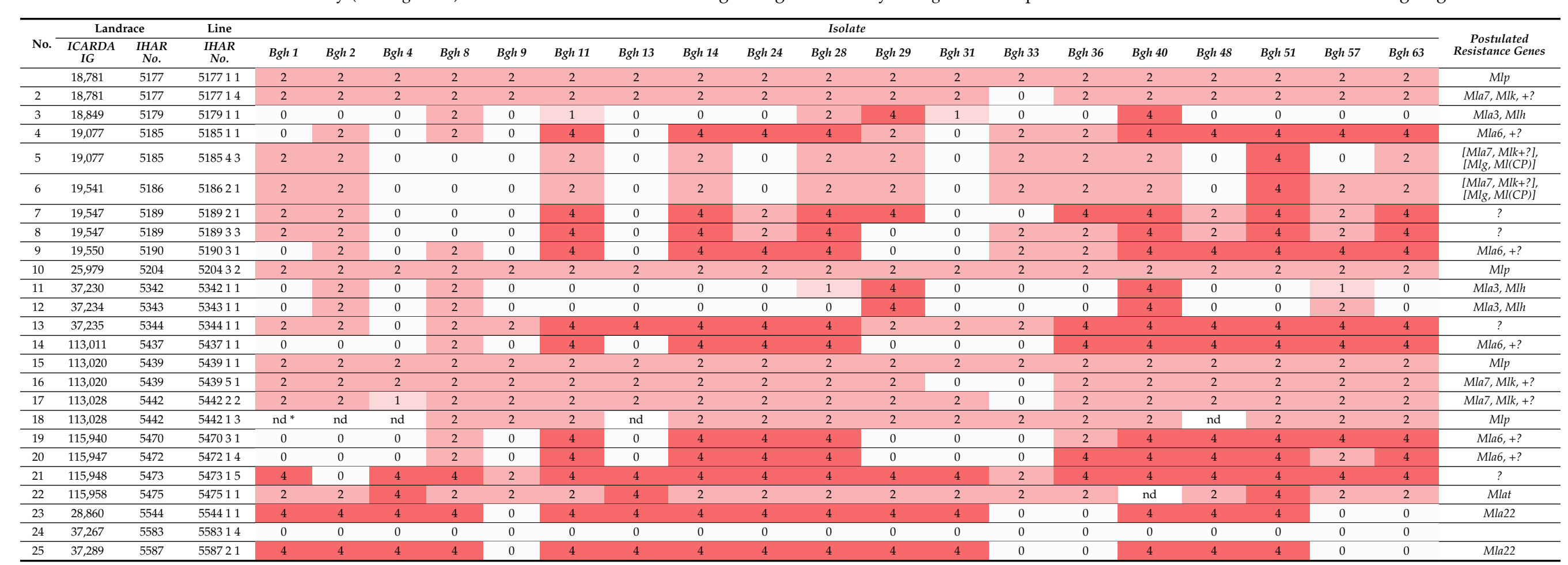

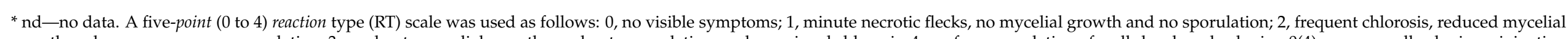

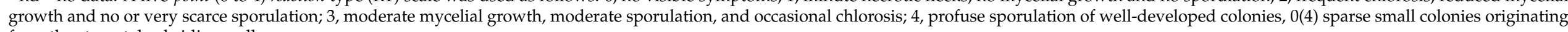
from the stomatal subsidiary cells. 


\section{Results}

Plants of 19 (14.7\%) of the tested landraces were resistant to infection with Bgh33 isolate in preliminary testing. In five landraces, segregation of RT was observed. Based on preliminary tests from these 19 landraces, 25 resistant, single plant lines were selected for testing with differential isolates. From these lines, seven were resistant to all 19 isolates used. However, only one line (5583-1-4) showed resistance scores of zero against all isolates used (Table 3). In five lines it was not possible to postulate the presence of specific resistance genes. In 19 lines, the presence of the genes Mlp, Mlk, Mlh, Mlg, Ml(CP), Mlat, Mla3, Mla6, Mla7, Mla22 and unknown genes (genes not present in differential set) were postulated.

\section{Discussion}

Barley landraces from Turkey are a rich source of genetic diversity for plant breeding, including resistance to powdery mildew $[10-12,38,39]$. This was confirmed in the presented study. Single plant lines selected from 19 (14.7\%) of the tested landraces were resistant to infection with powdery mildew.

Resistant lines selected from landraces are a very valuable material for resistance breeding. This kind of germplasm is the simplest source of resistance to use directly in breeding programs. Because of their adaptability to a wide range of conditions, barley landraces are recognized as an important genetic resource for tolerance and resistance to biotic and abiotic stresses. They carry unique traits and are considered a rich resource for resistance breeding and for the expansion of the gene pool $[45,46]$.

Turkey is a rich source of barley genetic diversity because of its geographic location. The south-eastern region of Turkey is at the top of the Fertile Crescent of the Near East, within the centre of origin of cultivated barley [39]. Barley is one of the oldest cultivated plants grown in Anatolia, and it is the second most important cereal crop following wheat. In addition, in Turkey, the ancestor of cultivated barley, Hordeum spontaneum C. Koch, grows naturally, and powdery mildew epidemics occur in the western and southern parts of the country [12]. All these factors lead to conclusion that coevolution of barley powdery mildew was occurring in Turkey for very long time, and that barley landraces from Turkey may be a rich source of resistance to powdery mildew. This was confirmed in the presented study, in which many resistance genes were identified in lines selected from Turkish landraces.

The genetic diversity of barley landraces offers many traits for barley breeding, especially concerning resistance to biotic and abiotic stresses [3,33,47-50]. The genetic heterogeneity within the barley landraces is due to a low level of outcrossing occurring in barley, and farmers' management of seed [40,51-53]. This genetic heterogeneity was also observed in the presented study, in which five landraces showed segregation of RT.

Many barley landraces collected in Tunisia [27], Morocco [36,54-59], Australia [60], China [61], Greece [62], Jordan [63,64], Egypt [54], Latvia [65], Libya [66], Yemen [67] and Spain [68-72] have been tested for resistance to powdery mildew, and numerous known and unknown specific resistances have been identified. In addition, collections of landraces from many countries have been studied [35,40,73-76]. Results show that the presence of known and unknown powdery mildew resistance genes have been obtained for barley landraces from Turkey $[10,38,39]$. The present study confirmed that barley landraces from Turkey have numerous known and unknown specific resistances to powdery mildew. In 24 resistant single-plant lines studied, the presence unknown resistance genes and the genes Mlp, Mlk, Mlh, Mlg, Ml(CP), Mlat, Mla3, Mla6, Mla7 and Mla22 were postulated.

Seedling resistance tests were used in order to describe infection types expressed by barley lines after inoculation with differentiated isolates of $B$. graminis $\mathrm{f}$. sp. hordei. This kind of testing is sufficient for disease-resistance screening. It is used commonly in breeding programmes to postulate the presence of specific resistance genes in modern cultivars and to screen germplasm for new sources of effective resistance $[36,40,75,76]$. However, these kinds of tests are not very useful for identifying and describing partial resistance. For a description of partial resistance there is a need to conduct measurements of resistance 
characteristics, in addition to the infection type. Furthermore, partial resistance is generally better expressed at the adult plant stage [26,34,77].

Newly identified sources of powdery mildew resistance in 25 single plant lines (originated from 19 landraces) are valuable for barley breeding for resistance. In five lines it was not possible to postulate the presence of specific resistance genes. In 19 lines the presence of the genes Mlp, Mlk, Mlh, Mlg, Ml(CP), Mlat, Mla3, Mla6, Mla7 and Mla22 and unknown genes (not present in differential set) were postulated. Interestingly for barley resistance breeding, seven lines selected from four landraces were resistant to all 19 isolates used in this study. However, the most interesting point from a breeders' point of view was line 5583-1-4, which showed resistance scores of zero for all isolates used. Most probably this line possesses unknown, yet very effective genes for resistance. Future work will include the genetic study of resistance identified in seven single-plant lines by conducting appropriate crosses and the use of molecular markers [58,59,78,79]. Authors intend to introduce these alleles into elite cultivars of barley to create initial materials for European breeding programmes. This is a necessary step between barley genebank collections and the practical use of barley genetic resources in breeding programmes. The new sources of highly effective powdery mildew resistance described in this study could be successfully used in barley breeding programs.

Author Contributions: Conceptualization, J.H.C.; methodology, J.H.C.; formal analysis, J.H.C. and E.C.; investigation, J.H.C.; resources, J.H.C.; writing-original draft preparation, project administration, J.H.C.; funding acquisition, J.H.C. All authors have read and agreed to the published version of the manuscript.

Funding: The results presented are based on evaluation carried out in the frame of the ECPGRfunded complementary module of the European Union project GENRES PL98-104 on barley genetic resources evaluation.

Institutional Review Board Statement: Not applicable.

Informed Consent Statement: Not applicable.

Data Availability Statement: Data are available in tables. Contact person is Jerzy H. Czembor, IHAR-PIB Radzików.

Acknowledgments: The results presented are based on evaluation carried out in the frame of the ECP/GR-funded complementary module of the European Union project GENRES PL98-104 on barley genetic resources evaluation. Authors thank J. Valkoun, J. Konopka and S. Ceccarelli (ICARDA, Aleppo, Syria) for providing seed samples of barley landrace from Turkey, H. J. Schaerer (ETH, Zurich, Switzerland) for the powdery mildew isolates, L. Munk (Royal Agricultural and Veterinary University, Copenhagen, Denmark) for the near-isogenic lines of 'Pallas'. Authors thank H. Knupffer, D. Enneking (IPK-Genebank, Gatersleben, Germany), L. Maggioni (ECP/GR, Rome, Italy) and W. Podyma (IHAR - Genebank, Radzikow, Poland) for providing the opportunity to conduct the research presented.

Conflicts of Interest: The authors declare no conflict of interest. Authors declare any personal circumstances or interest that may be perceived as inappropriately influencing the representation or interpretation of reported research results. Any role of the funders in the design of the study; in the collection, analyses or interpretation of data; in the writing of the manuscript, or in the decision to publish the results must be declared in this section.

\section{References}

1. Karagöz, A.; Özbek, K.; Akar, T.; Ergün, N.; Aydoğan, S.; Sayim, İ. Agro-Morphological Variation among an Ancient World Barley Collection. J. Agric. Sci. 2017, 23, 444-452. [CrossRef]

2. Kumar, A.; Verma, R.P.S.; Singh, A.; Sharma, H.K.; Devi, G. Barley landraces: Ecological heritage for edaphic stress adaptations and sustainable production. Environ. Sustain. Indic. 2020, 6, 100035. [CrossRef]

3. Ceccarelli, S.; Grando, S.; van Leur, J.A.G. Barley landraces of the fertile crescent offer new breeding options for stress environments. Diversity 1995, 11, 112-113.

4. Anonymous. FAOSTAT (2018) Barley Production. 2018. Available online: http://www.fao.org/faostat/en/\#data/QV (accessed on 10 September 2021). 
5. Anonymous; FAO. The second report on the state of the world's plant genetic resources for food and agriculture. In Commission on Genetic Resources for Food and Agriculture; Food and Agriculture Organization of the United Nations: Rome, Italy, $2010 ;$ p. 370.

6. Milner, S.G.; Jost, M.; Taketa, S.; Mazón, E.R.; Himmelbach, A.; Oppermann, M.; Weise, S.; Knüpffer, H.; Basterrechea, M.; König, P.; et al. Genebank genomics highlights the diversity of a global barley collection. Nat. Genet. 2019, 51, 319-326. [CrossRef] [PubMed]

7. Newton, A.C.; Akar, T.; Baresel, J.P.; Bebeli, P.J.; Bettencourt, E.; Bladenopoulos, K.V.; Czembor, J.H.; Fasoula, D.A.; Katsiotis, A.; Koutis, K.; et al. Cereal landraces for sustainable agriculture. A review. Agron. Sustain. Dev. 2010, 30, 237-269. [CrossRef]

8. Chabane, K.; Valkoun, J. Characterisation of Genetic Diversity in ICARDA Core Collection of Cultivated Barley (Hordeum vulgare L.). Czech J. Genet. Plant Breed. 2011, 40, 134-136. [CrossRef]

9. Marone, D.; Russo, M.A.; Mores, A.; Ficco, D.B.M.; Laidò, G.; Mastrangelo, A.M.; Borrelli, G.M. Importance of Landraces in Cereal Breeding for Stress Tolerance. Plants 2021, 10, 1267. [CrossRef]

10. Zeybek, A.; Şahin, D.; Gök, G.; Çallak, A.; Akkaya, M.S. Assessment of Powdery Mildew (Blumeria graminis f. sp. hordei) Resistance genes in Turkish barley varieties. Phytoprotection 2008, 89, 31-36. [CrossRef]

11. Akinci, C.; Yildirim, M. Screening of barley landraces by direct selection for crop improvement. Acta Agric. Scand. Sect. B Soil Plant Sci. 2009, 59, 33-41. [CrossRef]

12. Akgun, N.; Topal, A.; Akcura, M. Evaluation of cental Anatolian barley landraces for crop improvement. Rom. Agric. Res. 2012, 29, 87-93.

13. Murray, G.M.; Brennan, J.P. Estimating Disease Losses to the Australian Barley Industry. Australas. Plant Pathol. 2010, 39, 85-96. [CrossRef]

14. Savary, S.; Ficke, A.; Aubertot, J.N.; Hollier, C. Crop losses due to diseases and their implications for global food production losses and food security. Food Sec. 2012, 4, 519-537. [CrossRef]

15. Walters, D.R.; Avrova, A.; Bingham, I.J.; Burnett, F.J.; Fountaine, J.; Havis, N.D.; Hoad, S.P.; Hughes, G.; Looseley, M.; Oxley, S.J.P.; et al. Control of foliar diseases in barley: Towards an integrated approach. Eur. J. Plant Pathol. 2012, 133, 33-73. [CrossRef]

16. Kauppi, K.; Rajala, A.; Huusela, E.; Kaseva, J.; Ruuttunen, P.; Jalli, H.; Alakukku, L.; Jalli, M. Impact of Pests on Cereal Grain and Nutrient Yield in Boreal Growing Conditions. Agronomy 2021, 11, 592. [CrossRef]

17. Hovmøller, M.S.; Caffier, V.; Jalli, M.; Andersen, O.; Besenhofer, G.; Czembor, J.H.; Dreiseitl, A.; Flath, K.; Fleck, A.; Heinrics, F.; et al. The Eurpean barley powdery mildew virulence survey and disease nursery 1993-1999. Agronomie 2000, 20, 729-744. [CrossRef]

18. Dreiseitl, A. Adaptation of Blumeria graminis f. sp. hordei to barley resistance genes in the Czech Republic in 1971-2000. Plant Soil Environ. 2003, 49, 241-248. [CrossRef]

19. Dreiseitl, A. Differences in powdery mildew epidemics in spring and winter barley based on 30-year variety trials. Ann. Appl. Biol. 2011, 59, 49-57. [CrossRef]

20. Dreiseitl, A. Specific resistance of barley to powdery mildew, its use and beyond. A concise critical review. Genes 2020, $11,971$. [CrossRef]

21. Çelik Oğuz, A.; Karakaya, A. Genetic Diversity of Barley Foliar Fungal Pathogens. Agronomy 2021, 11, 434. [CrossRef]

22. Czembor, J.H.; Czembor, E. Mlo resistance of barley to powdery mildew (Blumeria graminis f.sp. hordei). Part I. Genetics, phenotype, mechanism and molecular investigations. Biul. IHAR 2003, 230, 335-354.

23. Czembor, J.H.; Czembor, E. Mlo resistance of barley to powdery mildew (Blumeria graminis f.sp. hordei). Part II. Sources of resistance and their use in barley breeding. Biul. IHAR 2003, 230, 355-374.

24. Czembor, J.H.; Czembor, E. Mlo resistance of barley to powdery mildew (Blumeria graminis f.sp. hordei) Part III. Durability of resistance. Biul. IHAR 2003, 230, 375-386.

25. Brown, J.K.M.; Jørgensen, J.H. A catalogue of mildew resistance genes in European barley varieties. In Integrated Control of Cereal Mildews: Virulence Patterns and Their Change; Jørgensen, J.H., Ed.; Risø National Laboratory: Roskilde, Denmark, 1991; pp. 263-286.

26. Jørgensen, J.H. Genetics of Powdery Mildew Resistance in Barley. Crit. Rev. Plant Sci. 1994, 13, 97-119. [CrossRef]

27. Czembor, J.H.; Johnston, M.R. Resistance to powdery mildew in selections from Tunisian landraces of barley. Plant Breed. 1999, 118, 503-509. [CrossRef]

28. Dreiseitl, A. Genes for resistance to powdery mildew in European barley cultivars registered in the Czech Republic from 2011 to 2015. Plant Breed. 2017, 136, 351-356. [CrossRef]

29. Dreiseitl, A. A novel resistance against powdery mildew found in winter barley cultivars. Plant Breed. 2019, 138, 840-845. [CrossRef]

30. Lamichhane, J.R.; Arseniuk, E.; Boonekamp, P.; Czembor, J.H.; Decroocq, V.; Enjalbert, J.; Finckh, M.; Korbin, M.; Koppel, M.; Kudsk, P.; et al. Advocating a need for suitable breeding approaches to boost integrated pest management: A European perspective. Pest Manag. Sci. 2017, 74, 1219-1227. [CrossRef]

31. Burdon, J.J.; Barrett, L.G.; Rebetzke, G.; Thrall, P.H. Guiding deployment of resistance in cereals using evolutionary principles. Evol Appl. 2014, 7, 609-624. [CrossRef] [PubMed]

32. Dreiseitl, A. Pathogenic divergence of Central European and Australian populations of Blumeria graminis f. sp. hordei. Ann. Appl. Biol. 2014, 165, 364-372. [CrossRef] 
33. Bonman, J.M.; Bockelman, H.E.; Jackson, L.F.; Steffenson, B.J. Disease and Insect Resistance in Cultivated Barley Accessions from the USDA National Small Grains Collection. Crop Sci. 2005, 45, 1271-1280. [CrossRef]

34. Shtaya, M.J.Y.; Marcel, T.C.; Sillero, J.C.; Niks, R.E.; Rubiales, D. Identification of QTL for powdery mildew and scald resistance in barley. Euphytica 2006, 151, 421-429. [CrossRef]

35. Camacho Villa, T.C.; Maxted, N.; Scholten, M.A.; Ford-Lloyd, B.V. Defining and identifying crop landraces. Plant Genet. Res. Characteriz. Utiliz. 2005, 3, 373-384. [CrossRef]

36. Jørgensen, J.H.; Jensen, H.P. Powdery mildew resistance in barley landrace material 1. Screening for resistance. Euphytica 1997, 97, 227-233. [CrossRef]

37. Czembor, J.H.; Czembor, H.J. Powdery mildew resistance in barley landraces from Morocco. J. Phytopathol. 2000, 148, 277-288. [CrossRef]

38. Czembor, J.H.; Czembor, H.J. Powdery mildew (Erysiphe graminis f. sp. hordei) resistance in barley landraces collected in Israel, Turkey and Iran. J. Agric. Environ. Int. Dev. 2000, 94, 275-296.

39. Czembor, J.H.; Frese, L. Powdery mildew resistance in selections from barley landraces collected from Turkey. Die Bodenkult. 2003, 54, 35-40.

40. Dreiseitl, A. Heterogeneity of powdery mildew resistance revealed in accessions of the ICARDA wild barley collection. Front. Plant Sci. 2017, 8, 202. [CrossRef]

41. Dreiseitl, A.; Zavřelová, M. Identification of barley powdery mildew resistances in gene bank accessions and the use of gene diversity for verifying seed purity and authenticity. PLoS ONE 2018, 13, e0208719. [CrossRef] [PubMed]

42. Kølster, P.; Munk, L.; Stølen, O.; Løhde, J. Near-isogenic barley lines with genes for resistance to powdery mildew. Crop Sci. 1986, 26, 903-907. [CrossRef]

43. Mains, E.B.; Dietz, S.M. Physiologic forms of barley mildew, Erysiphe graminis hordei Marchal. Phytopathology 1930, $20,229-239$.

44. Flor, H.H. The complementary genetic systems in flax and flax rust. Adv. Genet. 1956, 8, $29-54$.

45. Berhane, L.; Semeane, Y.F.; Gebre, H.; Grando, S.; van Leur, J.A.G.; Ceccarelli, S. Exploiting the diversity of barley landraces in Ethiopia. Genet. Res. Crop Evol. 1997, 44, 109-116. [CrossRef]

46. Akem, C.; Ceccarelli, S.; Erskine, W.; Lenne, J. Using genetic diversity for disease resistance in agricultural production. Outlook Agric. 2000, 29, 25-30. [CrossRef]

47. Monteagudo, A.; Casas, A.M.; Cantalapiedra, C.P.; Contreras-Moreira, B.; Gracia, M.P.; Igartua, E. Harnessing novel diversity from landraces to improve an elite barley variety. Front. Plant Sci. 2019, 10, 434. [CrossRef]

48. von Bothmer, R.; Sato, K.; Komatsuda, T.; Yasuda, S.; Fischbeck, G. The domestication of cultivated barley. In Diversity in Barley (Hordeum vulgare); von Bothmer, R., van Hintum, T., Knüpffer, H., Sato, K., Eds.; Elsevier Science B.V.: Amsterdam, The Netherlands, 2003; pp. 9-28.

49. Weibull, J.; Walther, U.; Sato, K.; Habekuß, A.; Kopahnke, D.; Proeseler, G. Diversity in resistance to biotic stresses. In Diversity in Barley (Hordeum vulgare); Von Bothmer, R., Van Hintum, T., Knüpffer, H., Sato, K., Eds.; Elsevier Science B.V.: Amsterdam, The Netherlands, 2003; pp. 143-178.

50. Madidi, S.E.; Diani, Z.; Aameur, F.B. Variation of agro-morphological characters in Moroccan barley landraces under near optimal and drought conditions. Genet. Res. Crop Evol. 2005, 52, 831-838. [CrossRef]

51. Parzies, H.K.; Spoor, W.; Ennos, R.A. Outcrossing rates of barley landraces from Syria. Plant Breed. 2000, 119, 520-522. [CrossRef]

52. van Leur, J.A.G.; Gebre, H. Diversity between some Ethiopian farmer's varieties of barley and within these varieties among seed sources. Genet. Res. Crop Evol. 2003, 50, 351-357. [CrossRef]

53. Abdel-Ghani, A.H.; Parzies, H.K.; Omary, A.; Geiger, H.H. Estimating the outcrossing rate of barley landraces and wild barley populations collected from ecologically different regions of Jordan. Theor. Appl. Genet. 2004, 109, 588-595. [CrossRef]

54. Czembor, J.H. Resistance to powdery mildew in barley (Hordeum vulgare L.) landraces from Egypt. J. Plant Genet. Resour. Newsl. 2000, 123, 52-60.

55. Czembor, J.H. Resistance to powdery mildew in populations of barley landraces from Morocco. Australas. Plant Pathol. 2000, 29, 137-148. [CrossRef]

56. Czembor, J.H.; Czembor, H.J. Identification of powdery mildew resistance genes in selections from Moroccan barley landraces. Acta Agric. Scand. Sect. B Soil Plant Sci. 2002, 52, 116-120. [CrossRef]

57. Jensen, H.R.; Dreiseitl, A.; Sadiki, M.; Schoen, D.J. The Red Queen and the seed bank: Pathogen resistance of ex situ and in situ conserved barley. Evol. Appl. 2012, 5, 353-367. [CrossRef] [PubMed]

58. Piechota, U.; Czembor, P.C.; Słowacki, P.; Czembor, J.H. Identifying a novel powdery mildew resistance gene in a barley landrace from Morocco. J. Appl. Genet. 2019, 60, 243-254. [CrossRef] [PubMed]

59. Piechota, U.; Słowacki, P.; Czembor, P.C. Identification of a novel recessive gene for resistance to powdery mildew (Blumeria graminis f. sp. hordei) in Barley (Hordeum vulgare). Plant Breed. 2020, 139, 730-742. [CrossRef]

60. Dreiseitl, A.; Platz, G. Powdery mildew resistance genes in barley varieties grown in Australia. Crop Pasture Sci. 2012, 63, 997-1006. [CrossRef]

61. Dreiseitl, A.; Yang, J. Powdery mildew resistance in a collection of Chinese barley varieties. Genet. Resour. Crop Evol. 2007, 54, 259-266. [CrossRef]

62. Czembor, J.H. Resistance to powdery mildew in selections from barley landraces collected in Greece. Agric. Food Sci. 2001, 10, 133-142. [CrossRef] 
63. Czembor, J.H.; Czembor, H.J. Resistance to powdery mildew in barley landraces collected from Jordan. Journal Plant Breeding and Seed Science 1999, 43, 67-83.

64. Abdel-Ghani, A.H.; Al-Ameiri, N.S.; Karajeh, M.R. Resistance of barley landraces and wild barley populations to powdery mildew in Jordan. Phytopathol. Mediterr. 2008, 47, 92-97. [CrossRef]

65. Dreiseitl, A.; Rashal, I. Powdery mildew resistance genes in Latvian barley varieties. Euphytica 2007, 135, 325-332. [CrossRef]

66. Czembor, J.H. Sources of resistance to powdery mildew in barley landraces from Libya. Sver. Utsadesf. Tidskrift J. Swedish Seed Assoc. 2000, 110, 232-248.

67. Czembor, J.H.; Czembor, E. Mlo Resistance to Powdery Mildew (Blumeria graminis f. sp. hordei) in Barley Landraces Collected in Yemen. Agronomy 2021, 11, 1582. [CrossRef]

68. Silvar, C.; Casas, A.M.; Kopahnke, D.; Habekuss, A.; Schweizer, G.; Gracia, M.P.; Lasa, J.M.; Ciudad, F.J.; Molina-Cano, J.L.; Igartua, E.; et al. Screening the Spanish barley core collection for disease resistance. Plant Breed. 2010, 129, 45-52. [CrossRef]

69. Silvar, C.; Casas, A.M.; Igartua, E.; Ponce-Molina, L.J.; Gracia, M.P.; Schweizer, G.; Herz, M.; Flath, K.; Waugh, R.; Kopahnke, D.; et al. Resistance to powdery mildew in Spanish barley landraces is controlled by different sets of quantitative trait loci. Theor. Appl. Genet. 2011, 123, 1019-1028. [CrossRef] [PubMed]

70. Silvar, C.; Flath, K.; Kopahnke, D.; Gracia, M.P.; Lasa, J.M.; Casas, A.M.; Igartua, E.; Ordon, F. Analysis of powdery mildew resistance in the Spanish barley core collection. Plant Breed. 2011, 130, 195-202. [CrossRef]

71. Silvar, C.; Kopahnke, D.; Flath, K.; Serfling, A.; Perovic, D.; Casas, A.M.; Igartua, E.; Ordon, F. Resistance to powdery mildew in one Spanish barley landrace hardly resembles other previously identified wild barley resistances. Eur. J. Plant Pathol. 2013, 136, 459-468. [CrossRef]

72. Silvar, C.; Perovic, D.; Nussbaumer, T.; Spannagl, M.; Usadel, B.; Casas, A.; Igartua, E.; Ordon, F. Towards positional isolation of three quantitative trait loci conferring resistance to powdery mildew in two Spanish barley landraces. PLoS ONE 2013, 8, e67336. [CrossRef] [PubMed]

73. Masterbroek, H.D.; Balkema Boomstra, A.G. Inheritance of resistance to powdery mildew (Erysiphe graminis f. sp. hordei) in 11 primitive barley varieties. Euphytica 1991, 57, 125-131. [CrossRef]

74. Surlan-Momirovic, G.; Flath, K.; Silvar, C.; Brankovic, G.; Kopahnke, D.; Knezevic, D.; Schliephake, E.; Ordon, F.; Perovic, D. Exploring the Serbian GenBank barley (Hordeum vulgare L. subsp vulgare) collection for powdery mildew resistance. Genet. Resour. Crop. Evol. 2016, 63, 275-287. [CrossRef]

75. Dreiseitl, A. Genotype Heterogeneity in Accessions of a Winter Barley Core Collection Assessed on Postulated Specific Powdery Mildew Resistance Genes. Agronomy 2021, 11, 513. [CrossRef]

76. Piechota, U.; Czembor, P.C.; Czembor, J.H. Evaluating barley landraces collected in North Africa and the Middle East for powdery mildew infection at seedling and adult plant stages. Cereal Res. Commun. 2020, 48, 179-185. [CrossRef]

77. Aghnoum, R.; Marcel, T.C.; Johrde, A.; Pecchioni, N.; Schweizer, P.; Niks, R.E. Basal host resistance of barley to powdery mildew. Connecting quantitative trait loci and candidate genes. Mol. Plant Microb. Interact. 2010, 23, 91-102. [CrossRef] [PubMed]

78. Hickey, L.T.; Lawson, W.; Platz, G.J.; Fowler, R.A.; Arief, V.; Dieters, M.; German, S.; Fletcher, S.; Park, R.F.; Singh, D.; et al. Mapping quantitative trait loci for partial resistance to powdery mildew in an Australian barley population. Crop. Sci. 2012, 52, 1021-1032. [CrossRef]

79. Hoseinzadeh, P.; Zhou, R.; Mascher, M.; Himmelbach, A.; Niks, R.E.; Schweizer, P.; Stein, N. High Resolution Genetic and Physical Mapping of a Major Powdery Mildew Resistance Locus in Barley. Front. Plant Sci. 2019, 10, 146. [CrossRef] [PubMed] 